\title{
Distribution pattern of Caragana species under the influence of climate gradient in the Inner Mongolia region, China
}

\author{
LiNa XIE ${ }^{1}$, ChengCang $\mathrm{MA}^{1 *}$, HongYu GUO ${ }^{1}$, QingFang $\mathrm{LI}^{1}$, YuBao GAO ${ }^{1,2}$ \\ ${ }^{1}$ Tianjin Key Laboratory of Animal and Plant Resistance, College of Life Sciences, Tianjin Normal University, Tianjin 300387, China; \\ ${ }^{2}$ College of Life Sciences, Nankai University, Tianjin 300071, China
}

\begin{abstract}
There is a strong climate gradient in the Inner Mongolia region, China, with solar radiation and air temperature increasing but precipitation decreasing gradually from the northeast to the southwest. Sixteen Caragana species exist in the Inner Mongolia region. These Caragana species exhibit a distribution pattern across moisture zones and form a geographical replacement series. In order to examine the mechanisms responsible for Caragana species distribution pattern, we selected 12 Caragana species that exhibit a distinct distribution pattern across multiple moisture zones in the Inner Mongolia region, and determined the relationships between the leaf ecological and physiological traits of these Caragana species and the aridity index and solar radiation. Along with the climatic drought gradient and the solar radiation intensification from the northeast to the southwest, leaf ecological characteristics of Caragana species changed drastically, i.e. the leaf shape gradually turned from flat into tegular or tubbish; the leaf hair became denser, longer and lighter in color; the leaf area, leaf biomass and specific leaf area (SLA) decreased significantly; the leaf thickness and the ratio of leaf thickness to leaf area increased significantly; and the leaf chlorophyll content decreased significantly. As the climatic drought stress increased, osmotic potentials of the main osmotic adjustment substances and the cytoplasmic ion concentration of Caragana species increased significantly. Meanwhile, the total and free water contents and water potential of leaves decreased significantly; the ratio of bound to free water increased significantly; the stomatal conductance and transpiration rate reduced significantly; and the water use efficiency (WUE) increased significantly. In addition, with the intensification of climatic drought stress, peroxidase (POD) and superoxide dismutase (SOD) activities in leaves increased significantly. As a result, the malondialdehyde (MDA) content increased while the oxygen free radical content decreased. Our results showed that most of the leaf ecological and physiological traits of the 12 Caragana species varied in accordance with the climatic drought gradient in the Inner Mongolia region, which reflected the adaptation of the Caragana species to the local climate conditions. With relatively more active metabolism and faster growth, the Caragana species in the northeast had strong competitive abilities; on the other hand, with stronger resistance to climatic drought stress, the Caragana species in the southwest could survive in harsh environments. Based on our results, we concluded that both the environmental gradients and the adaptive responses of Caragana species to their environments played important roles in the formation of the Caragana species distribution pattern across the Inner Mongolia region.
\end{abstract}

Keywords: adaptation; climatic gradient; morphological trait; osmotic potential; water state; water metabolism; antioxidative enzyme

Citation: LiNa XIE, ChengCang MA, HongYu GUO, QingFang LI, YuBao GAO. 2014. Distribution pattern of Caragana species under the influence of climate gradient in the Inner Mongolia region, China. Journal of Arid Land, 6(3): 311-323. doi: 10.1007/s40333-013-0227-2

Distribution pattern of plant species can be shaped by environmental factors, such as precipitation gradient (Pyke et al., 2001; Zhu et al., 2007), drought (Eeley et al., 1999), moisture and temperature gradients (McKenzie et al., 2003; Zhu et al., 2007), length of dry period, cumulative water deficit (Bongers et al.,

*Corresponding author: ChengCang MA (E-mail: machengcang@163.com)

Received 2013-04-16; revised 2013-07-21; accepted 2013-09-14

(C) Xinjiang Institute of Ecology and Geography, Chinese Academy of Sciences, Science Press and Springer-Verlag Berlin Heidelberg 2014 
1999), nocturnal warming (D’Odorico et al., 2013), habitat-mediated differences (Palmiotto et al., 2004), regional climate (Schmitt et al., 2013), belowground resource availability (John et al., 2007), and soil properties (Sollins, 1998). Meanwhile, it can also be influenced by the characteristics of plant species, such as drought tolerance (Engelbrecht et al., 2007; Comita and Engelbrecht, 2009) and plant responses to climate gradient (Retuerto and Carballeira, 2004). In short, distribution pattern of plant species reflects the evolutionary response of the species to the long-term environmental change (Thompson et al., 2013).

The climate in the Inner Mongolia region is characterized by a gradual increase in solar radiation and air temperature, and a gradual decrease in precipitation from the northeast to the southwest (Yang et al., 1987). The decrease in precipitation together with an increase in evaporation results in a climatic drought gradient from the northeast to the southwest. In the Inner Mongolia region, there are seven moisture-based zones from the northeast to the southwest: humid, sub-humid, semi-arid, droughty, very droughty, intensively droughty and extremely droughty zones. In accordance with these moisture-based zones, there are seven vegetation types: forest, meadow steppe, typical steppe, desert steppe, steppe desert, typical desert and extremely arid desert, respectively. With the climatic drought gradient, the Inner Mongolia region provides an ideal area for studying plant species adaptation to variable moisture conditions.

There are 16 Caragana species (deciduous shrubs) distributed in the Inner Mongolia region (Zhao, 1991). They exhibit a distribution pattern across moisture zones and form a geographical replacement series (Zhao, 1991; Zhou, 1996; Ma et al., 2012). Zhou (1996) studied the Caragana species in the Inner Mongolia region and suspected that the distribution pattern of these species in this region might be shaped by drought gradient, but the author did not demonstrate evidences in the aspects of climate gradient and corresponding plant traits. Examining the relationships between the climate gradient and the traits of Caragana species is critical in understanding the formation of Caragana distribution pattern in the Inner Mongolia region. However, very few studies have explicitly addressed this topic. In this study, we selected 12 Caragana species that exhibit a distinct distribution pattern across the moisture zones in the Inner Mongolia region, and determined the relationships between the leaf ecological and physiological traits of these Caragana species and the aridity index and solar radiation. The aim of this study is to illustrate the mechanisms, in the aspects of climate gradient and plant traits, responsible for Caragana species distribution pattern across the Inner Mongolia region.

\section{Study area and methods}

\subsection{Study area and plant species}

Inner Mongolia region is located in the northern China $\left(97^{\circ} 12^{\prime}-126^{\circ} 04^{\prime} \mathrm{E}, 37^{\circ} 24^{\prime}-53^{\circ} 23^{\prime} \mathrm{N}\right.$; $1,000 \mathrm{~m}$ asl), with a distance of $2,400 \mathrm{~km}$ from the east to the west and $1,700 \mathrm{~km}$ from the north to the south within the region. The total area of Inner Mongolia region is $1,183 \times 10^{3}$ $\mathrm{km}^{2}$, accounting for $12.3 \%$ of the total land area of China. Inner Mongolia region is characterized by a temperate continental monsoon climate, with relatively less and unevenly distributed precipitation, strong wind and dramatic seasonal changes. The mean annual precipitation in the whole region is $50-450$ $\mathrm{mm}$, which decreases from the northeast to the southwest gradually. The average annual sunshine duration in the region is more than $2,700 \mathrm{~h}$.

In this study, we selected 12 Caragana species that exhibit a distinct distribution pattern across the moisture zones as the target species. The distribution and morphological characteristics of these Caragana species are shown in Table 1. Field surveys on the 12 Caragana species were conducted at 14 study sites in the Inner Mongolia region in July of 2003, 2007 and 2012 (Fig. 1 and Table 2).

\subsection{Measurements of leaf ecological and physio- logical traits}

At each site, we set up three sampling plots (circle plots with a diameter of $50 \mathrm{~m}$ and distances of $20-40 \mathrm{~km}$ between them) for each Caragana species. In each plot, we took the following measurements on mature leaves from 30 Caragana plants (15-25 years old) to measure their leaf ecological and physiological traits. 
Table 1 Distribution and morphological characteristics of the 12 Caragana species in the Inner Mongolia region

\begin{tabular}{|c|c|c|c|c|c|}
\hline Species name & Distribution & $\begin{array}{l}\text { Moisture type of distribu- } \\
\text { tion zone }\end{array}$ & Leaf shape & Leaf hair & $\begin{array}{l}\text { Leaf hair } \\
\text { color }\end{array}$ \\
\hline C. sibirica & $\begin{array}{l}\text { Forest and forest-steppe zones close to } \\
\text { the northeast border }\end{array}$ & Humid to sub-humid & Flat & Few short & Bottle green \\
\hline C. opulens & $\begin{array}{l}\text { Shrubbery on the slope of Daqing Moun- } \\
\text { tain in the mid-south }\end{array}$ & Semi-arid & Flat & Few short & Bottle green \\
\hline C. microphylla & $\begin{array}{l}\text { Meadow steppe and typical steppe in the } \\
\text { northeast }\end{array}$ & Sub-humid to semi-arid & Flat & Few short & Bottle green \\
\hline C. davazamcii & $\begin{array}{l}\text { Desert steppe and steppe desert from the } \\
\text { middle to the mid-west }\end{array}$ & Droughty to very droughty & Flat & Medium & Light green \\
\hline C. brachypoda & $\begin{array}{l}\text { Desert steppe, steppe desert and typical } \\
\text { desert from the mid-west to the southwest }\end{array}$ & $\begin{array}{l}\text { Droughty to very droughty } \\
\text { to intensively droughty }\end{array}$ & Tegular & Medium & Bottle green \\
\hline C.pygmaea & Desert steppe in the middle and mid-west & Droughty & Tegular & Medium & Light green \\
\hline C. tibetica & $\begin{array}{l}\text { Steppe desert and typical desert in the } \\
\text { southwest }\end{array}$ & $\begin{array}{l}\text { Very droughty to inten- } \\
\text { sively droughty }\end{array}$ & Tubbish & Densely silky & Light green \\
\hline C. stenophylla & $\begin{array}{l}\text { Typical steppe, steppe desert and typical } \\
\text { desert form the middle to the southwest }\end{array}$ & $\begin{array}{l}\text { Semi-arid to very droughty } \\
\text { to intensively droughty }\end{array}$ & Tegular & Medium & Bottle green \\
\hline C. korshinskii & $\begin{array}{l}\text { Steppe desert and typical desert in the } \\
\text { southwest }\end{array}$ & $\begin{array}{l}\text { Very droughty to inten- } \\
\text { sively droughty }\end{array}$ & Flat & $\begin{array}{l}\text { Densely fallen } \\
\text { silky }\end{array}$ & Bright gray \\
\hline C. roborovskyi & $\begin{array}{l}\text { Typical desert and extremely arid desert } \\
\text { in the southwest }\end{array}$ & $\begin{array}{l}\text { Intensively droughty to } \\
\text { extremely droughty }\end{array}$ & Flat & $\begin{array}{l}\text { Densely } \\
\text { straight silky } \\
\text { hair }\end{array}$ & Bright gray \\
\hline C.jubata & $\begin{array}{l}\text { Shrubbery on the north slope of Helan } \\
\text { Mountain in the southwest }\end{array}$ & Intensively droughty & Flat & $\begin{array}{l}\text { Densely fallen } \\
\text { silky }\end{array}$ & Bright gray \\
\hline C. leucophloea & $\begin{array}{l}\text { Typical desert and extremely arid desert } \\
\text { in the southwest }\end{array}$ & $\begin{array}{l}\text { Intensively droughty to } \\
\text { extremely droughty }\end{array}$ & Tegular & Silky & Light green \\
\hline
\end{tabular}

The area of 100 leaves from 30 Caragana plants was measured using the CI-203 Portable Laser Area Meter (CID Co., USA), and the thickness of 100 leaf blades was measured with a vernier caliper. The biomass of 100 leaves was measured after drying, and then the specific leaf area (SLA) was calculated. Fresh leaves $(2 \mathrm{~g})$ were collected at 12:00-14:00 to determine the chlorophyll content (for methods and references, see Table 3).

In each plot, leaf samples $(15 \mathrm{~g})$ were collected at 12:00-14:00 and stored in liquid nitrogen in the laboratory to measure the osmotic potentials of the main osmotic adjustment substances (for methods and references, see Table 3). Osmotic potential was calculated according to the formula: $\psi s=R T \times n s / V w$. Where $\psi s$ is solute potential, $R$ is gas constant, $T$ is temperature in degrees $\mathrm{K}, n s$ is the number of moles of solutes, and $V w$ is the total water volume of the cell (i.e. leaf water content; Peltier et al., 1997).

Fresh leaves $(2 \mathrm{~g})$ were collected at 12:00-14:00 in each plot to determine the cytoplasmic ion concentra- tion. These fresh leave samples were cut into small pieces and mixed well, then $0.2 \mathrm{~g}$ subsample from the mixture was put into a tube with $10 \mathrm{ml}$ of distilled water, and the tube was boiled for $15 \mathrm{~min}$ to enable adequate diffusion of ions in cell into the water. We measured the electrical conductivity of the solution with a conductivity meter. The total water in leaves was treated as solvent to calculate the cytoplasmic ion concentration (expressed as electrical conductivity).

In each plot, we also collected fresh leaves $(2 \mathrm{~g})$ at 12:00-14:00 to determine the total, free and bound water contents and water potential (for methods and references, see Table 3).

The net photosynthesis, transpiration and stomatal conductance were measured using the LI-6400 Portable Photosynthesis System (LI-COR Co., USA) every $2 \mathrm{~h}$ from 07:00 to 19:00. We measured each plant for a total of 30 measurements per cycle $(2 \mathrm{~h})$, and then calculated the mean values of net photosynthesis, transpiration and stomatal conductance, respectively. Water use efficiency (WUE) was 
Table 2 Environmental data for the study sites

\begin{tabular}{|c|c|c|c|c|c|c|c|c|c|}
\hline Study site & $\begin{array}{l}\text { Longitude } \\
\text { (E) }\end{array}$ & $\begin{array}{l}\text { Latitude } \\
(\mathrm{N})\end{array}$ & $\begin{array}{l}\text { Altitude } \\
\text { (m) }\end{array}$ & $\begin{array}{c}\text { Annual } \\
\text { precipitation } \\
(\mathrm{mm})\end{array}$ & $\begin{array}{c}\text { Annual average } \\
\text { temperature } \\
\left({ }^{\circ} \mathrm{C}\right)\end{array}$ & $\begin{array}{l}\text { Sunshine } \\
\text { duration } \\
\text { (h) }\end{array}$ & $\begin{array}{l}\text { Soil water content } \\
(1-100 \mathrm{~cm} ; \%)\end{array}$ & $\begin{array}{c}\text { Aridity } \\
\text { index }\left(I_{\mathrm{dm}}\right)\end{array}$ & $\begin{array}{l}\text { Vegetation } \\
\text { type }\end{array}$ \\
\hline Zhalantun & $122^{\circ} 48^{\prime} 02^{\prime \prime}$ & $48^{\circ} 00^{\prime} 00^{\prime \prime}$ & 482 & 480 & 2.40 & 2,800 & 9.05 & 38.71 & Forest \\
\hline Hailar & $119^{\circ} 23^{\prime} 04^{\prime \prime}$ & $49^{\circ} 07^{\prime} 02^{\prime \prime}$ & 650 & 350 & -2.20 & 2,800 & 2.73 & 44.87 & $\begin{array}{l}\text { Forest-steppe } \\
\text { zone }\end{array}$ \\
\hline Xiwu & $117^{\circ} 36^{\prime} 00^{\prime \prime}$ & $44^{\circ} 34^{\prime} 08^{\prime \prime}$ & 996 & 340 & 1.47 & 2,870 & 4.09 & 29.64 & Typical steppe \\
\hline Xilinhot & $116^{\circ} 18^{\prime} 00^{\prime \prime}$ & $43^{\circ} 34^{\prime} 02^{\prime \prime}$ & 990 & 281 & 2.35 & 2,932 & 3.70 & 22.75 & Typical steppe \\
\hline Abaga & $114^{\circ} 58^{\prime} 02^{\prime \prime}$ & $44^{\circ} 04^{\prime} 00^{\prime \prime}$ & 1,126 & 245 & 1.20 & 3,047 & 3.09 & 21.88 & Desert steppe \\
\hline Suniteyou & $112^{\circ} 57^{\prime} 00^{\prime \prime}$ & $42^{\circ} 28^{\prime} 02^{\prime \prime}$ & 1,151 & 211 & 4.93 & 3,067 & 2.40 & 14.13 & Desert steppe \\
\hline Erenhot & $111^{\circ} 54^{\prime} 08^{\prime \prime}$ & $43^{\circ} 22^{\prime} 08^{\prime \prime}$ & 966 & 142 & 3.40 & 3,055 & 2.68 & 10.60 & Desert steppe \\
\hline Horinger & $111^{\circ} 52^{\prime} 08^{\prime \prime}$ & $40^{\circ} 19^{\prime} 08^{\prime \prime}$ & 1,063 & 420 & 5.60 & 2,942 & 9.21 & 26.92 & $\begin{array}{l}\text { Mountain slope } \\
\text { shrubbery }\end{array}$ \\
\hline Damao & $110^{\circ} 25^{\prime} 08^{\prime \prime}$ & $41^{\circ} 42^{\prime} 00^{\prime \prime}$ & 1,377 & 256 & 4.01 & 3,061 & 2.16 & 18.27 & Desert steppe \\
\hline Wulatezhong & $108^{\circ} 31^{\prime} 02^{\prime \prime}$ & $41^{\circ} 34^{\prime} 02^{\prime \prime}$ & 1,288 & 199 & 5.07 & 3,168 & 2.18 & 13.21 & Steppe desert \\
\hline Otog & $107^{\circ} 58^{\prime} 02^{\prime \prime}$ & $39^{\circ} 07^{\prime} 02^{\prime \prime}$ & 1,500 & 265 & 6.40 & 3,050 & 2.56 & 16.16 & Steppe desert \\
\hline Hangjinhou & $107^{\circ} 30^{\prime} 00^{\prime \prime}$ & $41^{\circ} 15^{\prime} 00^{\prime \prime}$ & 1,285 & 150 & 5.82 & 3,179 & 2.10 & 9.48 & Steppe desert \\
\hline Alashanzuo & $105^{\circ} 40^{\prime} 08^{\prime \prime}$ & $38^{\circ} 51^{\prime} 00^{\prime \prime}$ & 1,561 & 110 & 7.80 & 3,200 & 1.73 & 6.18 & Typical desert \\
\hline Alashanyou & $101^{\circ} 40^{\prime} 08^{\prime \prime}$ & $39^{\circ} 12^{\prime} 00^{\prime \prime}$ & 1,400 & 72 & 8.40 & 3,105 & 1.68 & 3.91 & $\begin{array}{c}\text { Extremely arid } \\
\text { desert }\end{array}$ \\
\hline
\end{tabular}

Note: Climate data are the mean values from 1961 to 2000; and soil water content data are the mean values from 3-6 sampling plots. Aridity index $\left(I_{\mathrm{dm}}\right)$ was calculated using de Martonne method (Meng et al., 2004).

calculated according to the formula: WUE $=$ daily average value of net photosynthesis/daily average value of transpiration.

For each plot, leaf samples $(2 \mathrm{~g})$ were collected at 12:00-14:00 and stored in liquid nitrogen in the laboratory to measure the antioxidative enzymes (peroxidase (POD), catalase (CAT) and superoxide dismutase (SOD)) activities and cell injury indices (malondialdehyde (MDA) content and oxygen free radical content). The measurement methods and references of these variables are shown in Table 3 .

Soil gravimetric water contents at depths of 30, 60 and $100 \mathrm{~cm}$ in each plot were measured respectively.

\subsection{Statistical analysis}

The mean value of each variable for each plot over 2003, 2007 and 2012 was calculated, and then these mean values were used in the statistical analyses. Each variable was analyzed using one-way ANOVA with species as factor and plot as replicate. Correlation analyses were performed between each variable (mean value for each species) and aridity index. The mean aridity index of the 14 study sites was 3.91-41.79. In addition, correlation analyses were also conducted between chlorophyll content and local annual sunshine duration. The mean annual sunshine duration in the 14 study sites ranged from 2,800 to $3,200 \mathrm{~h}$. All the statistic analyses were performed using SPSS 16.0.

\section{Results}

\subsection{Leaf ecological traits}

Along with the climatic drought gradient and the intensification of solar radiation from the northeast to 


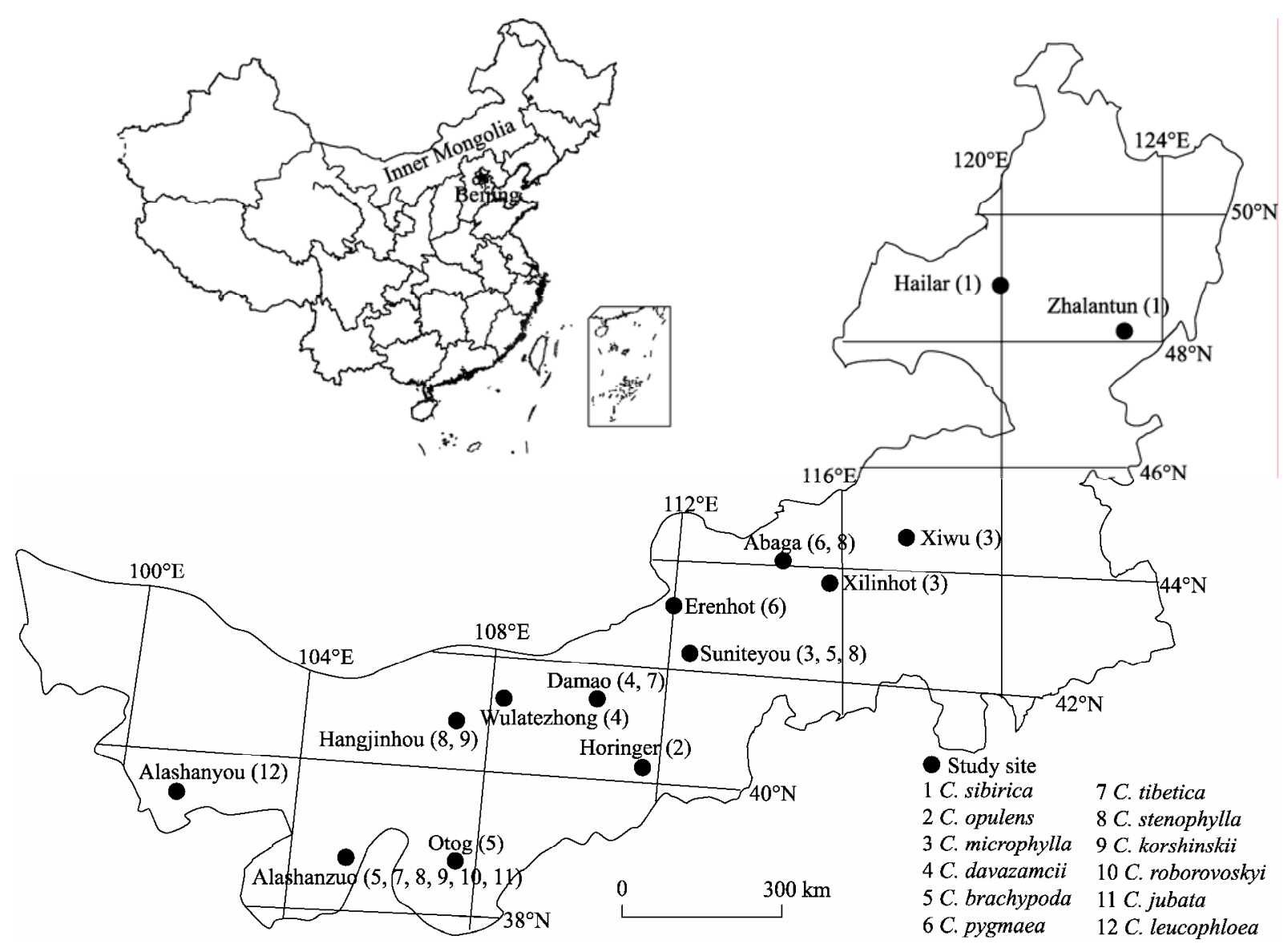

Fig. 1 Study sites and 12 Caragana species in the Inner Mongolia region

Table 3 The variables measured and methods (or references) used in the extermination of leaf physiological traits

\begin{tabular}{|c|c|}
\hline Variable & Method or reference \\
\hline Chlorophyll content & Lichtenthaler et al., 1996 \\
\hline Soluble protein content & Bradford, 1976 \\
\hline Free amino acid content & Lee and Takahashi, 1966 \\
\hline Organic acid content & Sinclair et al., 1945 \\
\hline Soluble sugar content & Buysse and Merckx, 1993 \\
\hline $\begin{array}{l}\mathrm{K}^{+}, \mathrm{Na}^{+}, \mathrm{Ca}^{2+}, \mathrm{Mg}^{2+}, \mathrm{Cu}^{2+}, \mathrm{Zn}^{2+} \\
\text { and } \mathrm{Mn}^{2+} \text { contents }\end{array}$ & $\begin{array}{l}\text { Atomic Absorption } \\
\text { Spectr-photometer }\end{array}$ \\
\hline $\mathrm{Cl}^{-}$content & Schales and Schales, 1941 \\
\hline $\mathrm{NO}_{3}{ }^{-}$and $\mathrm{NO}_{2}{ }^{-}$contents & Marzinzig et al., 1997 \\
\hline $\begin{array}{l}\text { Total, free and bound water } \\
\text { contents }\end{array}$ & Pissis et al., 1987 \\
\hline Water potential & HR-33T dew point instrument \\
\hline Peroxidase (POD) activity & Naveh et al., 1981 \\
\hline Catalase (CAT) activity & Goldblith and Proctor, 1950 \\
\hline $\begin{array}{l}\text { Superoxide dismutase (SOD) } \\
\text { activity }\end{array}$ & Beyer Jr and Fridovich, 1987 \\
\hline $\begin{array}{l}\text { Malondialdehyde (MDA) } \\
\text { content }\end{array}$ & Agarwal and Chase, 2002 \\
\hline Oxygen free radical content & Bors et al., 1978 \\
\hline
\end{tabular}

the southwest, the leaf shape of different Caragana species in the study sites gradually turned from flat into tegular or tubbish (Table 1). With the intensification of drought and solar radiation, the leaf area decreased $(F=419.719, P<0.01)$, while the leaf thickness increased significantly $(F=15.307, P<0.01)$, and the ratio of leaf thickness to leaf area also increased significantly $(F=93.405, P<0.01)$. Additionally, all these three variables were significantly correlated with aridity index (Figs. 2a-c). The leaf biomass $(F=139.473$, $P<0.01)$ and SLA $(F=55.169, P<0.01)$ decreased significantly with the drought intensification. Moreover, the two variables were also significantly correlated with aridity index (Figs. $2 \mathrm{~d}$ and e). Thus, the light absorbent area and transpiration area of leaf reduced gradually with the intensification of climatic drought stress and solar radiation.

As the climatic drought stress and solar radiation increased, the foliar hair of Caragana species became denser, longer and lighter in color from the northeast 

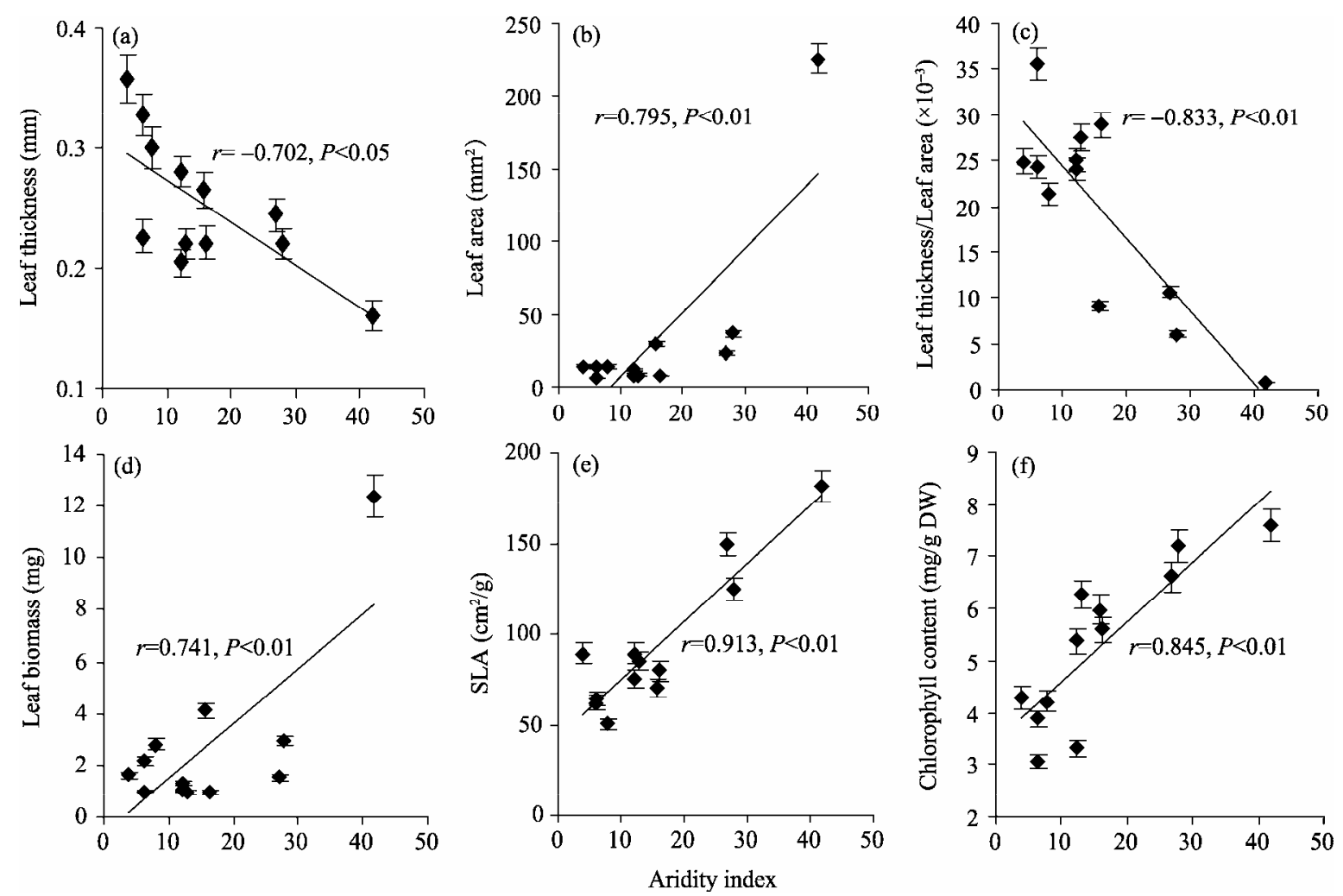

Fig. 2 Correlations between leaf ecological traits ((a), leaf thickness; (b), leaf area; (c), leaf thickness/leaf area; (d), leaf biomass; (e), SLA (specific leaf area); (f), chlorophyll content) of Caragana species and aridity index (mean $\pm S E$ )

to the southwest (Tables 1 and 2). The chlorophyll content in leaves decreased gradually with the intensification of climatic drought stress and solar radiation $(F=43.462, P<0.01)$, showing a significant positive correlation with aridity index $(r=0.845, P<0.01$; Fig. 2f) and a significant negative correlation with annual sunshine duration $(r=-0.832, P<0.01)$. Thus, the light-reflecting ability of leaf in Caragana species gradually became stronger with the increases of climatic drought stress and solar radiation.

\subsection{Leaf osmotic potentials of the main osmotic adjustment substances and cytoplasmic ion concentration}

There were no clear relationships between the osmotic potentials of soluble protein, free amino acid and organic acid with the climatic drought gradient (Figs. 3a and b). While, as the climatic drought stress increased from the northeast to the southwest, the osmotic potentials of soluble sugar $(F=12.593, P<0.01)$ and inorganic ions $\left(\mathrm{K}^{+}, F=15.550, P<0.01 ; \mathrm{Cl}^{-}, F=21.727\right.$, $P<0.01 ; \mathrm{Ca}^{2+}, F=32.954, P<0.01 ; \mathrm{Mg}^{2+}, F=27.755$,
$P<0.01 ; \mathrm{Na}^{+}, F=14.553, P<0.01 ; \mathrm{NO}_{3}^{-}$and $\mathrm{NO}_{2}^{-}$, $F=2.279, P=0.052 ; \mathrm{Cu}^{2+}, F=2.199, P=0.059 ; \mathrm{Zn}^{2+}$, $\left.F=17.718, P<0.01 ; \mathrm{Mn}^{2+}, F=4.476, P<0.01\right)$ in the leaves of Caragana species increased significantly. The osmotic potentials of soluble sugar and inorganic ions (except for $\mathrm{Zn}^{2+}, P>0.05$ ) and the total osmotic potential showed significant negative correlation with aridity index (Figs. 3c-h). The cytoplasmic ion concentration in Caragana species leaves increased significantly $(F=87.661, P<0.01)$ with the increase of climatic drought stress, and there was a significant negative correlation between cytoplasmic ion concentration and aridity index (Fig. 3i).

\subsection{Leaf water states and water potential}

With the increase of climatic drought stress from the northeast to the southwest, the total and free water contents of Caragana species leaves decreased significantly $(F=85.835, P<0.01$ and $F=9.913, P<0.01$, respectively), whereas the bound water content tended to increase $(F=1.473, P=0.215)$. The total and free 

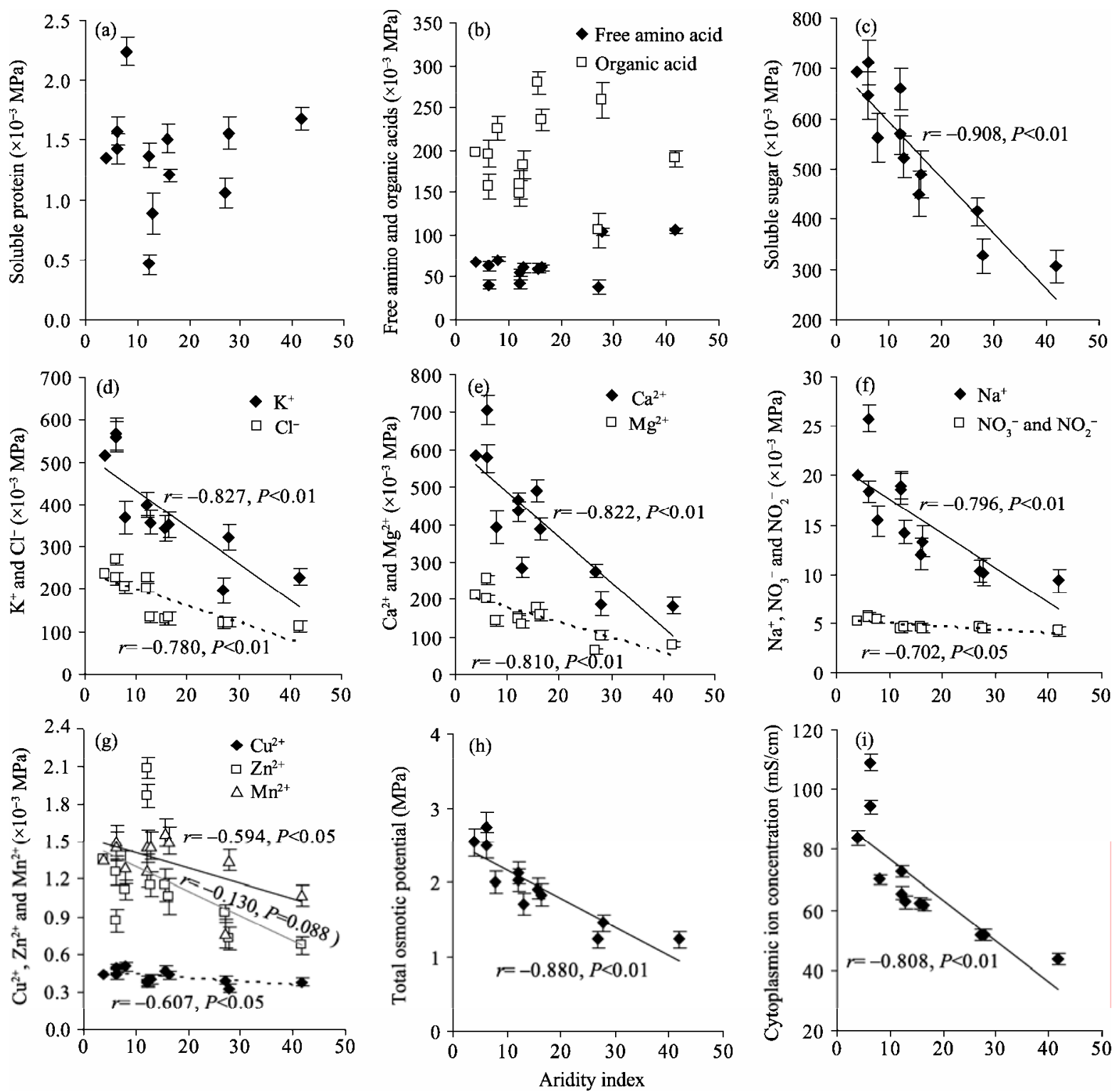

Fig. 3 Correlations between osmotic potentials of the main osmotic adjustment substances ((a), soluble protein; (b), free amino and organic acids; (c), soluble sugar; (d), $\mathrm{K}^{+}$and $\mathrm{Cl}^{-}$; (e), $\mathrm{Ca}^{2+}$ and $\mathrm{Mg}^{2+}$; (f), $\mathrm{Na}^{+}, \mathrm{NO}_{3}^{-}$and $\mathrm{NO}_{2}^{-} ;$(g), $\mathrm{Cu}^{2+}, \mathrm{Zn}^{2+}$ and $\mathrm{Mn}^{2+}$; (h), total osmotic potential) and cytoplasmic ion concentration (i) of Caragana species leaves and aridity index (mean $\pm \mathrm{SE})$

water contents were significantly positively correlated with aridity index, but the bound water content had a negative correlation with aridity index (Figs. $4 \mathrm{a}$ and b). The ratio of bound to free water content decreased significantly with the increase in aridity index $(F=68.096, P<0.01$; Fig. $4 \mathrm{c})$, while the water potential increased significantly with the increase of aridity index ( $F=80.267, P<0.01$; Fig. $4 d$ ).

\subsection{Leaf water metabolisms}

With the increase of climatic drought stress from the northeast to the southwest, the stomatal conductance
$(F=8.189, P<0.01)$ and transpiration rate $(F=8.657$, $P<0.01)$ in leaves of Caragana species decreased significantly, and they both showed significant positive correlations with aridity index (Figs. 5a and b). It seemed that the ability of Caragana species to reduce water loss through stomatal adjustment increased gradually with the increase of climatic drought stress. The WUE in leaves of Caragana species increased significantly with the increase of climatic drought stress $(F=13.345, P<0.01)$, presenting a significant negative correlation with aridity index (Fig. 5c). 

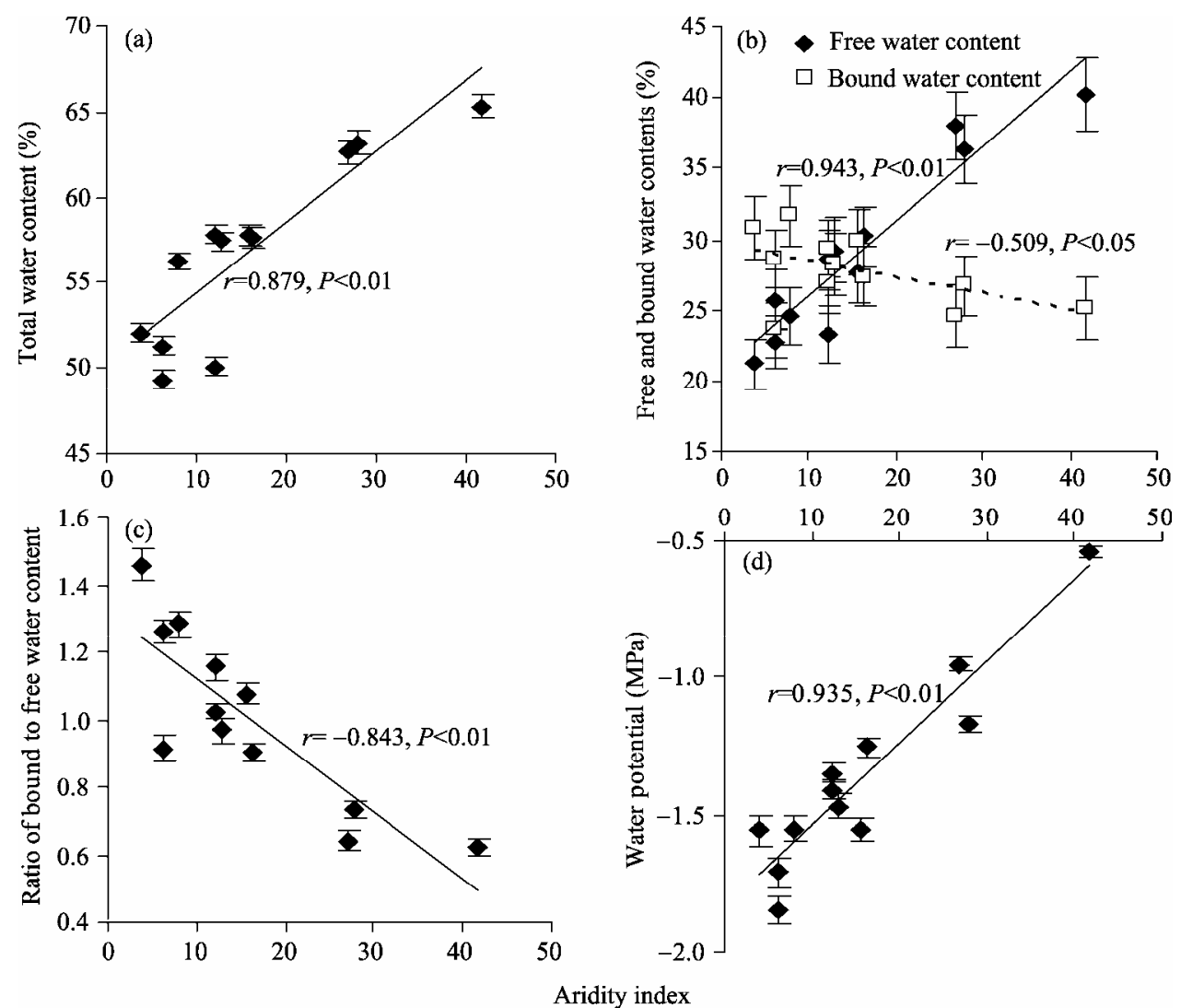

Fig. 4 Correlations between leaf water states ((a), total water content; (b), free and bound water contents; (c) ratio of bound to free water content) and water potential (d) of Caragana species and aridity index (mean \pm SE)
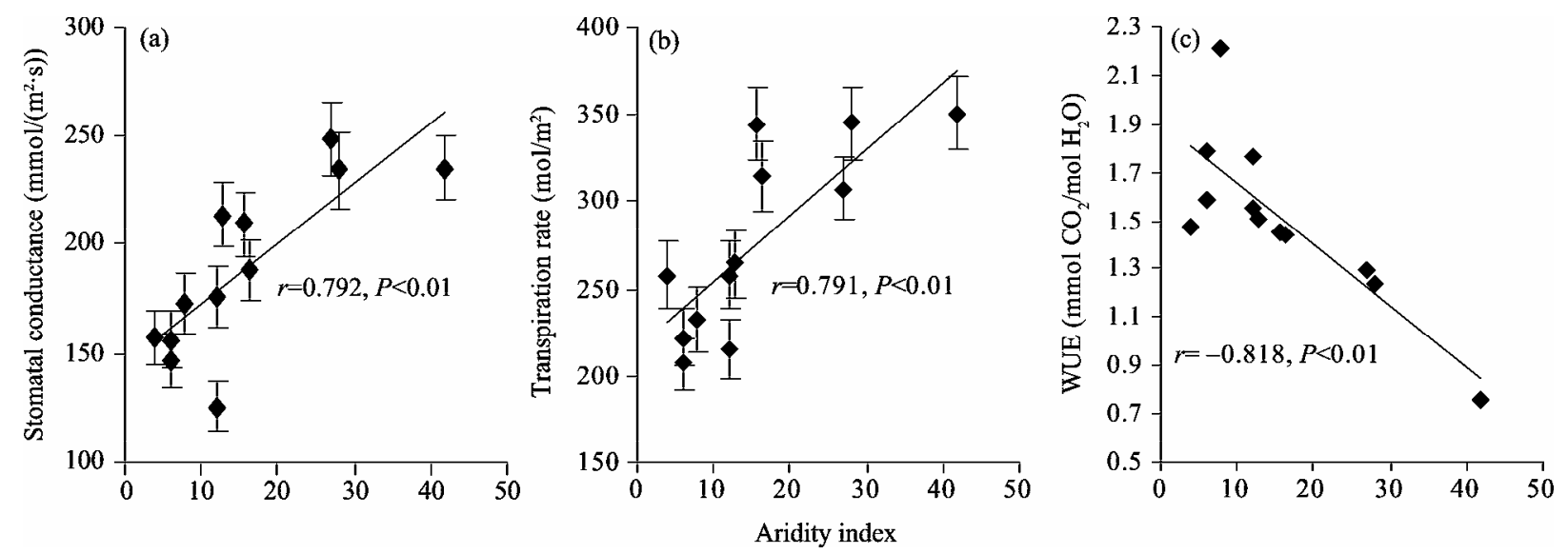

Fig. 5 Correlations between water metabolisms ((a), stomatal conductance; (b), transpiration rate; (c), WUE (water use efficiency)) in leaves of Caragana species and aridity index (mean \pm SE)

\subsection{Leaf antioxidative enzyme activities and cell injury indices}

As the climatic drought stress increased, the POD and SOD activities in leaves of Caragana species increased but the CAT activity did not show a significant increase. The POD and SOD activities were negatively correlated with aridity index (Table 4). Meanwhile, as the climatic drought stress increased, the MDA content increased while the oxygen free radical content decreased, and these two variables showed significant correlations with aridity index. 
Table 4 Results of ANOVA and correlation analyses on the leaf antioxidative enzyme activities and cell injure indices of Caragana species across the climatic drought gradient

\begin{tabular}{|c|c|c|c|c|c|}
\hline & POD activity & CAT activity & SOD activity & MDA content & Oxygen free radical content \\
\hline \multirow{2}{*}{ ANOVA } & $F=134.972$ & $F=31.530$ & $F=5.550$ & $F=1.510$ & $F=9.682$ \\
\hline & $P<0.01$ & $P<0.01$ & $P<0.01$ & $P=0.201$ & $P<0.01$ \\
\hline \multirow{2}{*}{ Correlation with aridity index } & $r=-0.569$ & $r=0.258$ & $r=-0.607$ & $r=-0.873$ & $r=0.576$ \\
\hline & $P<0.05$ & $P=0.418$ & $P<0.05$ & $P<0.01$ & $P<0.05$ \\
\hline
\end{tabular}

Note: POD, peroxidase; CAT, catalase; SOD, superoxide dismutase; MDA, malondialdehyde.

\section{Discussion}

\subsection{Relationship between leaf ecological traits and climate gradient}

Plants can adapt to environments with different moisture and radiation conditions through variable leaf ecological traits. The characteristics of reduced leaf area, increased leaf thickness, decreased leaf biomass, dense and bright leaf hair, and light leaf color may act to reduce light absorption and transpiration (Le Roux and Bariac, 1998; Quarrie et al., 1999; Jiang, 2000; Machado and Paulsen, 2001; Cabuslay et al., 2002). The plant species growing in environments with intensive sunlight, high temperature or serious drought stress usually have lower chlorophyll content (Pintado et al., 1997; Voronin et al., 2003; Zhang et al., 2003; Zhu et al., 2003). Caragana species (such as C. sibirica and C. microphylla) in the northeast Inner Mongolia region grow in humid forest or sub-humid to semi-arid steppes, where both solar radiation and air temperature are relatively lower than those in the southwest region. Larger light absorption area and stronger light absorption ability (few, short and green foliar hair, and high chlorophyll content) would favor photosynthesis, which enabled the Caragana species distributed in the northeast region to utilize solar energy more effectively, thereby maintaining high growth rate. In contrast, in the southwest region where the environment is extremely arid with strong solar radiation and high temperature, the smaller transpiration area and stronger leaf light-reflecting ability (dense, long and light-colored leaf hair, and low chlorophyll content) in Caragana species (such as C. tibetica, C. roborovskyi and C. jubata) would benefit the growth of these plants by reducing light absorption and decreasing transpiration (Fig. 5b). These ecologi- cal traits then generally would improve the water retention ability of these species, but simultaneously might reduce the growth and development rates of these plants.

\subsection{Relationship between leaf physiological traits and climate gradient}

Plants can also adapt to environmental conditions through leaf physiological traits. It is well known that water regulation ability is vital for plants to adapt to different moisture environments (Sánchez et al., 1998). Osmotic adjustment is an important mechanism for plants to absorb water and maintain turgor (Morgan, 1984; Guicherd et al., 1997; Peltier et al., 1997; Patakas et al., 2002). As the climatic drought stress increased from the northeast to the southwest, the osmotic potential in leaves of Caragana species increased gradually, which enabled the Caragana species distributed in the southwest region to absorb sufficient water, and thereby survive in arid environments. The content of soluble sugars in the leaf tissue of Caragana species increased significantly with the intensification of drought stress, and these sugars made considerable contribution to the increase of cell osmotic potential $(23 \%$ to $33 \%)$. This result suggests that, as climatic drought stress increases, Caragana species will allocate more photosynthetic products for maintaining cell osmotic potential and water balance. In the northeast region where the environmental conditions are relatively favorable for Caragana species, more photosynthetic products are devoted to the growth and development of these species. In contrast, in the southwest region with strong climatic drought stress, survivorship seems to be more important than growth and development for Caragana species.

It has been shown that the free and bound water levels can also play important roles in plant adaptation 
to different moisture environments. Plant species with more total leaf water and free water would have more active metabolism (Hanson and Hitz, 1982). On the other hand, species with more bound water would have stronger drought resistance (Al-Saadi and Wiebe, 1973; Jiang, 2000). Our results on the free and bound water in leaves of Caragana species indicated that, with the intensification of climatic drought stress from the northeast to the southwest, the drought resistance of Caragana species increased gradually. More total and free water in leaves of Caragana species distributed in the northeast region enabled them to have a more active metabolism. In contrast, higher content of bound water and higher ratio of bound to free water in leaves of Caragana species distributed in the southwest region reduced metabolic rate, while strengthened the drought resistance of these Caragana species, which enabled these species to survive in the harsh environments.

With the intensification of climatic drought stress, the leaf water potential of Caragana species decreased gradually. The lower leaf water potential in the Caragana species of the southwest region might enable them to extract more soil water to maintain water balance. This mechanism reflects the strong osmotic adjustment ability of Caragana species (Marigo et al., 2000; Ma et al., 2008).

Reduction of stomatal conductance and transpiration rate is critical for plants to maintain water balance in arid environments (Wang et al., 1996; Yang et al., 1997; Franca et al., 2000). High WUE is an important trait for drought-tolerant plants, and is a water-saving strategy for plants to survive in arid regions (Ares and Fownes, 1999; Ma et al., 2003a). The variation of stomatal adjustment ability among the 12 Caragana species was in accordance with the changes in the climatic conditions of their distribution areas. The greater stomatal conductance in the Caragana species of the northeast region was probably favorable to photosynthesis, although more water was consumed through transpiration (Fig. 5b). In the southwest region, although low stomatal conductance reduced water loss (Fig. 5b), it also restricted photosynthesis rate to some extent, so that Caragana species can survive in the southwest by sacrificing their growth rate. The leaf WUE of Caragana species increased significantly with the intensification of climatic drought stress, indicating that the Caragana species in the southwest region might take a water-saving strategy for adaptation to the arid environments.

Antioxidative enzyme system is an important physiological basis for plants to survive in harsh environments. SOD, POD and CAT are the major antioxidative enzymes that can remove oxygen free radicals from plants (Wang and Li, 2001; Lima et al., 2002). The activities of POD and SOD in Caragana species increased gradually from the northeast to the southwest. As a result, the oxygen free radical content might decrease with the increase of climatic drought stress. Having increasingly active antioxidative enzymes might be one of the important traits for the Caragana species in the southwest to adapt to the arid environments.

\subsection{The formation of Caragana species distrib- ution pattern across the Inner Mongolia re- gion}

By the middle stage of the Tertiary Period (approximately 20 million years ago (MYA)), the climate on the Eurasian Continent was temperate and moist, and the topography was flat and open. Caragana species originated from the same ancestor during the Miocene Period (16-14 MYA), and spread rapidly over the Asian Continent (Zhou, 1996; Ma et al., 2003b; Zhang and Fritsch, 2010). During the Miocene Period, with the Himalayan motion (21-17 MYA) and the rapid uplift of the Qinghai-Tibetan Plateau (approximately 8 MYA), the Central Asia region became progressively arid, but the climatic conditions had not changed substantially in Eastern Asia region (Guo et al., 2008; Zhang and Fritsch, 2010). As a result, a climatic drought gradient formed in the Inner Mongolia region. Shifts in climatic conditions have driven the evolution and diversification of Caragana species, which enabled these species to successfully adapt to the environments in the Inner Mongolia region (Zhang and Fritsch, 2010). Thus, the distribution pattern of Caragana species formed along with the establishment of the climatic gradients in the Inner Mongolia region. For the 12 Caragana species in this study, most of the leaf ecological and physiological traits varied in ac- 
cordance with the climatic drought gradient. The leaf biological traits of Caragana species showed significant correlations with the climatic drought gradient, suggesting that Caragana species can well adapt to the local climatic conditions. With the relatively greater metabolism and faster growth rate, the Caragana species in the northeast have strong competitive ability; on the other hand, with stronger resistance to stress especially to climatic drought stress, the Caragana species in the southwest are able to survive in the harsh environments.

\section{Conclusions}

In this study, we examined the relationships between the leaf ecological and physiological traits of 12 Caragana species with aridity index and solar radiation in the Inner Mongolia region. Our results showed that most of the leaf ecological and physiological traits of the 12 Caragana species varied in accordance with the climatic drought gradient, which reflected the adaptation of the Caragana species to the local climate conditions. These results suggested that both the progressive development of the climate gradient pattern and the different adaptive strategies among the Caragana species to variable moisture environments played important roles in the formation of Caragana species distribution pattern across the Inner Mongolia region.

\section{Acknowledgments}

This research was funded by the National Natural Science Foundation of China (31170381, 31100330) and the National Basic Research Program of China (2007CB106802). We thank Dr. YiZhi ZHAO from Inner Mongolia University for his advice on the field surveys and his help in identifying the plant species.

\section{References}

Agarwal R, Chase S D. 2002. Rapid, fluorimetric-liquid chromatographic determination of malondialdehyde in biological samples. Journal of Chromatography B, 775: 121-126.

Al-Saadi H, Wiebe H H. 1973. Survey of the matric water of various plant groups. Plant and Soil, 39: 253-261.

Ares A, Fownes J H. 1999. Water supply regulates structure, productivity, and water use efficiency of Acacia koa forest in Hawaii.
Oecologia, 121: 458-466.

Beyer Jr W F, Fridovich I. 1987. Assaying for superoxide dismutase activity: Some large consequences of minor changes in conditions. Analytical Biochemistry, 161: 559-566.

Bongers F, Poorter L, Van Rompaey R S A P, et al. 1999. Distribution of twelve moist forest canopy tree species in Liberia and Cote d'Ivoire: response curves to a climatic gradient. Journal of Vegetation Science, 10: 371-382.

Bors W, Saran M, Lengfelder E, et al. 1978. Detection of oxygen radicals in biological reactions. Photochemistry and Photobiology, 28: 629-637.

Bradford M M. 1976. A rapid and sensitive method for the quantitation of microgram quantities of protein utilizing the principle of protein-dye binding. Analytical Biochemistry, 72: 248-254.

Buysse J, Merckx R. 1993. An improved colorimetric method to quantify sugar content of plant tissue. Journal of Experimental Botany, 44: 1627-1629.

Cabuslay G S, Ito O, Alejar A A. 2002. Physiological evaluation of responses of rice (Oryza sativa L.) to water deficit. Plant Science, 163: 815-827.

Comita L S, Engelbrecht B M J. 2009. Seasonal and spatial variation in water availability drive habitat associations in a tropical forest. Ecology, 90: 2755-2765.

D’Odorico P, He Y F, Collins S, et al. 2013. Vegetation-microclimate feedbacks in woodland-grassland ecotones. Global Ecology and Biogeography, 22: 364-379.

Eeley H A C, Lawes M J, Piper S E. 1999. The influence of climate change on the distribution of indigenous forest in KwaZulu-Natal, South Africa. Journal of Biogeography, 26: 595-617.

Engelbrecht B M J, Comita L S, Condit R, et al. 2007. Drought sensitivity shapes species distribution patterns in tropical forests. Nature, 447: 80-82.

Franca M G C, Thi A T P, Pimentel C, et al. 2000. Differences in growth and water relations among Phaseolus vulgaris cultivars in response to induced drought stress. Environmental and Experimental Botany, 43: 227-237.

Goldblith S A, Proctor B E. 1950. Photometric determination of catalase activity. Journal of Biological Chemistry, 187: 705-709.

Guicherd P, Peltier J P, Gout E, et al. 1997. Osmotic adjustment in Fraxinus excelsior L.: malate and mannitol accumulation in leaves under drought conditions. Trees, 11: 155-161.

Guo Z T, Sun B, Zhang Z S, et al. 2008. A major reorganization of Asian climate by the early Miocene. Climate Past, 4: 153-174.

Hanson A D, Hitz W D. 1982. Metabolic responses of mesophytes to plant water deficits. Annual Review of Plant Physiology, 33: 163-203.

Jiang Z R. 2000. Probe into drought-resisting mechanism of Ammopiptanthus mongolicus (Maxim) Cheng F. Journal Desert Research, 20(1): 71-74.

John R, Dalling J W, Harms K E, et al. 2007. Soil nutrients influence 
spatial distributions of tropical tree species. Proceedings of the National Academy of Sciences of the United States of America, 104: 864-869.

Le Roux X, Bariac T. 1998. Seasonal variation in soil, grass and shrub water status in a West African humid savanna. Oecologia, 113: 456-466.

Lee Y P, Takahashi T. 1966. An improved colorimetric determination of amino acids with the use of ninhydrin. Analytical Biochemistry, 14: 71-77.

Lichtenthaler H K, Gitelson A, Lang M. 1996. Non-destructive determination of chlorophyll content of leaves of a green and an aurea mutant of tobacco by reflectance measurements. Journal of Plant Physiology, 148: 483-493.

Lima A L S, DaMatta F M, Pinheiro H A, et al. 2002. Photochemical responses and oxidative stress in two clones of Coffea canephora under water deficit conditions. Environmental and Experimental Botany, 47: 239-247.

Ma C C, Gao Y B, Guo H Y, et al. 2003a. Interspecific transition between Caragana microphylla, C. davazamcii and C. korshinskii along geographic gradient. II. Characteristics of photosynthesis and water metabolism. Acta Botanica Sinica, 45(10): 1228-1237.

Ma C C, Gao Y B, Liu H F, et al. 2003b. Interspecific transition between Caragana microphylla, C. davazamcii and C. korshinskii along geographic gradient. I. Ecological and RAPD evidence. Acta Botanica Sinica, 45(10): 1218-1227.

Ma C C, Gao Y B, Guo H Y, et al. 2008. Physiological adaptations of four dominant Caragana species in the desert region of the Inner Mongolia Plateau. Journal of Arid Environments, 72: 247-254.

Ma C C, Guo H Y, Li Q F, et al. 2012. Geographical variation of physiological and morphological traits among populations of three Caragana species in Inner Mongolia Steppe. Journal of Food, Agriculture and Environment, 10: 1233-1239.

Machado S, Paulsen G M. 2001. Combined affects of drought and high temperature on water relations of wheat and sorghum. Plant and Soil, 233: 179-187.

Marigo G, Peltier J P, Girel J, et al. 2000. Success in the demographic expansion of Fraxinus excelsior L. Trees, 15: 1-13.

Marzinzig M, Nussler A K, Stadler J, et al. 1997. Improved methods to measure end products of nitric oxide in biological fluids: nitrite, nitrate, and S-nitrosothiols. Nitric Oxide, 1: 177-189.

McKenzie D, Peterson D W, Peterson D L, et al. 2003. Climatic and biophysical controls on conifer species distributions in mountain forests of Washington State, USA. Journal of Biogeography, 30: 1093-1108.

Meng M, Ni J, Zhang Z G. 2004. Aridity index and its applications in geo-ecological study. Acta Phytoecologica Sinica, 28(6): 853-861.

Morgan J M. 1984. Osmoregulation and water stress in higher plants. Annual Review of Plant Physiology, 35: 299-319.

Naveh D, Mizrahi S, Kopelman I J. 1981. Quantitative determination of peroxidase in sweet corn by chemiluminescence. Journal of Agricultural and Food Chemistry, 29: 36-38.
Palmiotto P A, Davies S J, Vogt K A, et al. 2004. Soil-related habitat specialization in dipterocarp rain forest tree species in Borneo. Journal of Ecology, 92: 609-623.

Patakas A, Nikolaou N, Zioziou E, et al. 2002. The role of organic solute and ion accumulation in osmotic adjustment in drought-stressed grapevines. Plant Science, 163: 361-367.

Peltier J P, Marigo D, Marigo G. 1997. Involvement of malate and mannitol in the diurnal regulation of the water struts in members of oleaceae. Trees, 12: 27-34.

Pintado A, Valladares F, Sancho L G. 1997. Exploring phenotypic plasticity in the lichen Ramalina capitata: morphology, water relations and chlorophyll content in north- and south-facing populations. Annals of Botany, 80: 345-353.

Pissis P, Angnostopoulou-Konsta A, Apekis L. 1987. A dielectric study of the state of water in plant stems. Journal of Experimental Botany, 38: 1528-1540.

Pyke C R, Condit R, Aguilar S, et al. 2001. Floristic composition across a climatic gradient in a neotropical lowland forest. Journal of Vegetation Science, 12: 553-566.

Quarrie S A, Stojanović J, Pekić S. 1999. Improving drought resistance in small-grained cereals: A case study, progress and prospects. Plant Growth Regulation, 29: 1-21.

Retuerto R, Carballeira A. 2004. Estimating plant responses to climate by direct gradient analysis and geographic distribution analysis. Plant Ecology, 170: 185-202.

Sánchez F J, Manzanares M, de Andres E F, et al. 1998. Turgor maintenance, osmotic adjustment and soluble sugar and proline accumulation in 49 pea cultivars in response to water stress. Field Crops Research, 59: 225-235.

Schales O, Schales S S. 1941. A simple and accurate method for the determination of chloride in biological fluids. Journal of Biological Chemistry, 140: 879-884.

Schmitt C B, Senbeta F, Woldemariam T, et al. 2013. Importance of regional climates for plant species distribution patterns in moist Afromontane forest. Journal of Vegetation Science, 24: 553-568.

Sinclair W B, Bartholomew E T, Ramsey R C. 1945. Analysis of the organic acids of orange juice. Plant Physiology, 20: 3-18.

Sollins P. 1998. Factors influencing species composition in tropical lowland rain forest: does soil matter? Ecology, 79: 23-30.

Thompson J, Charpentier A, Bouguet G, et al. 2013. Evolution of a genetic polymorphism with climate change in a Mediterranean landscape. Proceedings of the National Academy of Sciences of the United States of America, 110: 2893-2897.

Voronin P Y, Ivanova L A, Ronzhina D A, et al. 2003. Structural and functional changes in the leaves of plants from steppe communities as affected by aridization of the Eurasian climate. Russian Journal of Plant Physiology, 50: 604-611.

Wang J, Li D Q. 2001. The accumulation of plant osmoticum and actived oxygen metablism under stress. Chinese Bulletin of Botany, 18(4): $459-465$.

Wang M B, Li H J, Cai B F. 1996. Water ecophysiological characteristics 
of Caragana korshinskii. Acta Phytoecologica Sinica, 20(6): 494-501.

Yang M H, Guo Z D, Wang C G. 1987. Remote sensing explains about Inner Mongolia Municipality climate types. In: Chen K, Li B. Application Study on Remote Sensing in Inner Mongolia Pasture Resource. Huhehot: Inner Mongolia University Press, 46-58.

Yang W B, Ren J M, Jia C P. 1997. Studies on the relationship between physiological ecology of drought-resistance in Caragana korshinskii and soil water. Acta Ecologica Sinica, 17(3): 239-244.

Zhang M L, Fritsch P W. 2010. Evolutionary response of Caragana (Fabaceae) to Qinghai-Tibetan Plateau uplift and Asian interior aridification. Plant Systematics and Evolution, 288: 191-199.

Zhang S, Ma K, Chen L. 2003. Response of photosynthetic plasticity of Paeonia suffruticosa to changed light environment. Environmental and Experimental Botany, 49: 121-133.

Zhao Y Z. 1991. Classification and eco-geographical distribution of Caragana in Nei Mongol. Acta Scientiarum Naturalium Universitis Intramongolicae, 22(2): 264-273.

Zhou D W. 1996. Study on distribution of the genus Caragana Fabr. Bulletin of Botanical Research, 16(4): 428-435.

Zhu H, Ma Y X, Yan L C, et al. 2007. The relationship between geography and climate in the generic-level patterns of Chinese seed plants. Acta Phytotaxonomica Sinica, 45: 134-166.

Zhu X Y, Wang S M, Zhang C L. 2003. Composition and characteristic differences in photosynthetic membranes of two ecotypes of reed (Phragmites communis L.) from different habitats. Photosynthetica, 41: 97-104. 